\title{
TGF-beta I levels are associated with lymphocyte percentages in patients with lung cancer treated with radiation therapy
}

This article was published in the following Dove Press journal:

OncoTargets and Therapy

\author{
Jing Luo ${ }^{1-3}$ \\ Sainan $\mathrm{Hu}^{4}$ \\ Tingting $\mathrm{Wei}^{1-3}$ \\ Jifeng Sun ${ }^{1-3}$ \\ Ningbo Liu ${ }^{1-3}$ \\ Jun Wang ${ }^{1-3}$
}

'Department of Radiation Oncology, Tianjin Medical University Cancer Institute and Hospital, National Clinical Research Center for Cancer, ${ }^{2}$ Key Laboratory of Cancer Prevention and Therapy, ${ }^{3}$ Tianjin's Clinical Research Center for Cancer, Tianjin 300060, China; ${ }^{4}$ Jiangsu Cancer Hospital, Jiangsu Institute of Cancer Research, The Affiliated Cancer Hospital of Nanjing Medical University, Nanjing 210000, China
Correspondence: Ningbo Liu Department of Radiation Oncology, Tianjin Lung Cancer Center, Tianjin Medical University Cancer Hospital and Institute, Hexi District, Huanhuxi Road, Tiyuanbei, Tianjin 300060, China Tel +86I8622227323

Email liuningbo@tjmuch.com
Purpose: Plasma TGF- $\beta 1$ protein levels reportedly may predict the treatment outcomes of lung cancer. We hypothesized that in patients with lung cancer treated with radiation therapy (RT), TGF- $\beta 1$ levels may correlate with the percentages of $\mathrm{CD} 4^{+} \mathrm{T}$ cells, $\mathrm{CD} 8^{+} \mathrm{T}$ cells, and the $\mathrm{CD}^{+} / \mathrm{CD}^{+} \mathrm{T}$ cell ratio in peripheral blood.

Patients and methods: Eighty-two lung cancer patients satisfied the inclusion criteria. Platelet-poor plasma was obtained before RT, at the second and fourth weeks during RT, and at the end of RT (pre-, during-, and post-RT, respectively). TGF- $\beta 1$ was measured via ELISA, while recording the percentages of lymphocyte subsets in peripheral blood. Short-term efficacy was categorized as complete response, partial response, stable disease, or progressive disease.

Results: Patients who had significantly lower TGF- $\beta 1$ protein levels after RT than pre-RT seemed to have a better short-term effect $(P<0.05)$ than those who had higher TGF- $\beta 1$ levels. There was a significant association between the TGF- $\beta 1$ levels and percentages of $\mathrm{CD}^{+}$ $\mathrm{T}$ cells, $\mathrm{CD} 8^{+} \mathrm{T}$ cells, or $\mathrm{CD} 4^{+} / \mathrm{CD}^{+} \mathrm{T}$ cell ratio during and at the end of $\mathrm{RT}$. Changes in $\mathrm{CD}^{+} \mathrm{T}$ cells, B cells, or natural killer cells were not statistically related to the changes in TGF- $\beta 1$ levels.

Conclusion: Lung cancer patients with TGF- $\beta 1$ levels in plasma after RT that are below pre-RT levels may experience better short-term efficacy. The underlying mechanism may be related to the influence of TGF- $\beta 1$ on antitumor immunity.

Keywords: lung cancer, radiotherapy, TGF- $\beta 1$, lymphocytes, prognosis

\section{Introduction}

Lung cancer is the leading cause of cancer-related death in the world. It has been reported that TGF- $\beta 1$ levels in the lung cancer tissues of patients, ${ }^{1-4}$ or in plasma, may be associated with prognosis of the disease. ${ }^{5,6}$ In locally advanced non-small-cell lung cancer (NSCLC), an increase in TGF- $\beta 1$ levels in plasma during radiation therapy (RT) indicates a poorer prognosis. This may relate to immune escape or suppression induced by TGF- $\beta 1$ at the end of RT. ${ }^{7-9}$ To the best of our knowledge, no studies have investigated the possible associations between plasma TGF- $\beta 1$ levels and the lymphocytes $\mathrm{CD}^{+} \mathrm{T}$ cells, $\mathrm{CD}^{+} \mathrm{T}$ cells, or $\mathrm{CD}^{+} / \mathrm{CD}^{+} \mathrm{T}$ cell ratio.

This study investigated the prognostic significance of plasma TGF- $\beta 1$ levels during RT in the treatment of lung cancer, and the possible correlations during the course of RT between TGF- $\beta 1$ levels and $\mathrm{CD}^{+} \mathrm{T}$ cell or $\mathrm{CD}^{+} \mathrm{T}$ cell levels, or the $\mathrm{CD}^{+} /$ $\mathrm{CD}^{+} \mathrm{T}$ cell ratio. 


\section{Materials and methods Study design}

Ethical approval for this investigation was obtained from the Research Ethics Committee, Tianjin Cancer Hospital \& Institute. In brief, 82 patients with lung cancer were included in the final analysis. Blood samples were collected at the following timepoints: within a week prior to receiving RT (pre-RT), at the second and fourth weeks during RT ( 2 weeks during-RT or 4 weeks during-RT), and within a week after RT (post-RT). The blood samples were analyzed for CD4+ $\mathrm{T}$ cells, $\mathrm{CD} 8^{+} \mathrm{T}$ cells, $\mathrm{B}$ cells, and natural killer (NK) cells, and the $\mathrm{CD}^{+} / \mathrm{CD}^{+} \mathrm{T}$ cell ratio was calculated. TGF- $\beta 1$ levels were investigated for associations with $\mathrm{CD}^{+} \mathrm{T}$ cell or $\mathrm{CD}^{+} \mathrm{T}$ cell levels, or $\mathrm{CD} 4^{+} / \mathrm{CD}^{+} \mathrm{T}$ cell ratio.

The response to RT treatment was evaluated by chest computed tomography (CT) image 1 month after RT, and classified as a complete or partial response, or stable or progressive disease. The short-term efficacy of treatment was then categorized as effective (complete or partial response) or ineffective (stable or progressive disease). The response rates were evaluated to determine the prognostic value of plasma TGF- $\beta 1$ levels during RT.

\section{Patients}

We identified all patients with lung cancer, confirmed and treated at Tianjin Cancer Hospital, between March 1, 2016, and May 1, 2017. After appropriate eligibility was established, 82 patients with lung cancer participated. All patients involved in this study were informed of the content of the research and provided written informed consent.

All the participating patients had lung cancer, confirmed by pathology or cytology in Tianjin Cancer Hospital. Excluded from the analysis was any patient with medical complications or serious infectious diseases that could affect immune function; obvious contraindications for intensitymodulated RT; malignant tumors other than lung cancer; receiving immune therapy or taking immunosuppressive drugs within the previous 3 months; incomplete medical records; or who did not comply with the criteria mentioned above, gave up the treatment for various reasons, or were otherwise lost to follow-up.

\section{Radiotherapy}

All patients received RT with or without sequential or concurrent chemotherapy. Radiation was given via consistent intensity-modulated RT. Treatment planning was performed with a Philips Pinnacle ${ }^{3}$ radiation treatment planning system (Philips Medical Systems, Amsterdam, Netherlands).
For all patients, gross tumor volume was identified based on the CT images. The gross tumor volume included the tumor and the metastatic lymph nodes. The clinical target volume was based on the gross tumor volume, but also included the primary tumor bed and metastatic lymph nodes before chemotherapy. The distance from the margin of the gross tumor volume to the clinical target volume was $5 \mathrm{~mm}$. The distance from the margin of the clinical target volume to the planning target volume was $5-10 \mathrm{~mm}$. The radiation dose was 50-66 Gy in 20-33 fractions, 1.8-3 Gy per fraction, 1 fraction per day.

\section{Chemotherapy}

Chemotherapy was given before, during, or after RT, or at combinations of these intervals. When chemotherapy was given sequentially with RT, small-cell lung cancer (SCLC) patients received chemotherapy of etoposide and cisplatin, or etoposide and carboplatin. NSCLC patients received chemotherapy of platinum-based doublets (carboplatin or cisplatin combined with vinorelbine, paclitaxel, or gemcitabine). When chemotherapy was given concurrently, the combination of carboplatin or cisplatin and etoposide or paclitaxel was commonly used. The dosage of all the chemotherapy drugs was within normal limits. A chemotherapy cycle was considered to be 21 days. The median number of chemotherapy cycles was 4 .

\section{Sample collection and TGF- $\beta$ I measurement}

Blood samples were collected, with dipotassium EDTA as the anticoagulant, at 3 timepoints as described above in the study design. Blood samples were placed on ice immediately after collection. Blood samples were centrifuged within 2 hours of collection at $3,000 \times g$ for 30 minutes. The upper onethird of the supernatants was collected and stored at $-80^{\circ} \mathrm{C}$. Plasma TGF- $\beta 1$ levels were then measured by enzyme-linked ELISA using a Quantikine ELISA Kit (R\&D Systems, Inc., Minneapolis, MN, USA). The presence of $\mathrm{CD}^{+} \mathrm{T}$ cells, $\mathrm{CD}^{+} \mathrm{T}$ cells, $\mathrm{CD} 4^{+} / \mathrm{CD}^{+} \mathrm{T}$ cell ratio, $\mathrm{B}$ cells, and $\mathrm{NK}$ cells was tested by the Department of Clinical Laboratory, Tianjin Cancer Hospital. FACSCanto ${ }^{\text {TM }}$ II flow cytometer (BD Biosciences, San Jose, CA, USA) was used to finish the measurement of lymphocyte percentages.

\section{Criteria for evaluating therapeutic effect}

The response rate was evaluated by chest CT image, 1 month after RT. In accordance with the Response Evaluation Criteria in Solid Tumors version 1.1, short-term efficacy was 
classified as a complete response, partial response, stable disease, or progressive disease. Immeasurable lesions (such as bone metastasis sites or malignant pleural effusion) were generally not evaluated, unless involved in disease progression. Effective treatment was defined as a complete or partial response after RT. Ineffective treatment was defined as stable disease or progressive disease after RT.

\section{Statistical analysis}

Clinical characteristics were compared using the chi-squared test. The Mann-Whitney $U$ test was used to compare differences in TGF- $\beta 1$ in plasma and lymphocytes, while two-tailed Student's $t$-test was used to compare the same patients with different timepoints. Independent $t$-test and oneway ANOVA were used to compare differences in TGF- $\beta 1$ between different clinical characteristics. Correlations were tested by Pearson's correlation analysis. All $P$-values were two-sided. Data are presented as mean \pm SD unless otherwise specified.

\section{Results}

\section{Clinical characteristics of patients}

In this prospective study, 104 patients with lung cancer were initially considered for inclusion, and subsequently
22 patients were excluded for the following reasons: 11 received a diagnosis of esophageal cancer; 5 were found with thymoma; and 6 were missing data. Thus, 82 patients were included in the final analysis; different clinical characteristics are listed in Table 1 . In addition, patients with different clinical characteristics also had similar TGF- $\beta 1$ levels (Table 1).

\section{Association between TGF- $\beta$ I levels and short-term response to treatment}

Of the whole group, 47 (57\%) achieved an effective response (CR+PR), and 35 (43\%) achieved an ineffective response (SD+PD; Table 2). At different timepoints, TGF- $\beta 1$ levels varied. Furthermore, patients with SCLC and NSCLC also had different TGF- $\beta 1$ levels (Table 2). The TGF- $\beta 1$ levels of the patients before RT were comparable $(P>0.05$; Table 2$)$. After RT, the mean TGF- $\beta 1$ levels of the patients who had shown an effective response were significantly lower than that of the patients for whom RT was ineffective $(P<0.05$; Table 2$)$.

Overall, 47 patients showed an effective response to RT, while treatment was ineffective for 35 patients (Table 3). Of those with an effective response, the majority (36/47) had TGF- $\beta 1$ levels after RT that were lower than the pre-RT levels. The TGF- $\beta 1$ levels of most of the patients who showed

Table I Clinical characteristics and TGF- $\beta$ I levels $(\mathrm{ng} / \mathrm{mL})$ of the 82 patients

\begin{tabular}{|c|c|c|c|c|c|}
\hline & $\mathbf{n}$ & TGF- $\beta I^{a}$ & $P$-value ${ }^{a}$ & TGF- $\beta$ I $^{\mathrm{b}}$ & $P$-value ${ }^{b}$ \\
\hline Gender & & & 0.827 & & 0.274 \\
\hline Male & 51 & $2.8 I \pm 0.42$ & & $2.52 \pm 0.47$ & \\
\hline Female & 31 & $3.02 \pm 1.07$ & & $3.81 \pm 1.37$ & \\
\hline Age (years) & & & 0.483 & & 0.093 \\
\hline$\geq 65$ & 30 & $3.32 \pm 0.83$ & & $4.13 \pm 1.30$ & \\
\hline$<65$ & 52 & $2.69 \pm 0.45$ & & $2.33 \pm 0.43$ & \\
\hline Histological type & & & 0.078 & & 0.247 \\
\hline SCLC & 21 & $2.74 \pm 0.46$ & & $2.83 \pm 0.67$ & \\
\hline Adenocarcinoma & 30 & $1.57 \pm 0.18$ & & $4.68 \pm 1.68$ & \\
\hline SCC & 30 & $3.4 I \pm 0.83$ & & $2.4 I \pm 0.65$ & \\
\hline Others & 1 & 1.30 & & 1.48 & \\
\hline Stage & & & 0.053 & & 0.389 \\
\hline I & I & 1.14 & & 0.81 & \\
\hline II & 36 & $3.31 \pm 1.68$ & & $2.14 \pm 0.64$ & \\
\hline III & $4 I$ & $2.55 \pm 0.36$ & & $2.90 \pm 0.58$ & \\
\hline IV & 4 & $4.40 \pm 1.65$ & & $3.22 \pm 1.70$ & \\
\hline Radiation dose, Gy & & & 0.362 & & 0.858 \\
\hline$\geq 60$ & 76 & $2.80 \pm 0.40$ & & $2.80 \pm 0.48$ & \\
\hline$<60$ & 6 & 5.08 & & 2.26 & \\
\hline Chemotherapy cycles & & & 0.098 & & 0.017 \\
\hline$\geq 4$ & 46 & $2.40 \pm 0.38$ & & $2.0 \mathrm{I} \pm 0.37$ & \\
\hline$<4$ & 36 & $3.77 \pm 0.85$ & & $4.35 \pm 1.10$ & \\
\hline
\end{tabular}

Notes: ${ }^{\text {PPre-RT. }}$ 'Post-RT. TGF- $\beta$ I levels did not show statistical significance of the 82 patients in different clinical characteristics. Abbreviations: RT, radiation therapy; SCC, squamous cell carcinoma; SCLC, small-cell lung cancer. 
Table 2 TGF- $\beta$ I levels ( $\mathrm{ng} / \mathrm{mL}$ ) of the 82 lung cancer patients at 4 timepoints by treatment efficacy

\begin{tabular}{|c|c|c|c|c|c|c|}
\hline & \multicolumn{3}{|l|}{ SCLC } & \multicolumn{3}{|l|}{ NSCLC } \\
\hline & CR+PR & SD+PD & $P$-value & CR+PR & SD+PD & $P$-value \\
\hline Subjects, $\mathrm{n}$ & 12 & 9 & - & 35 & 26 & - \\
\hline Pre-RT & $2.80 \pm 0.43$ & $2.66 \pm 0.95$ & 0.81 & $2.70 \pm 0.84$ & $3.42 \pm 1.16$ & 0.61 \\
\hline \multicolumn{7}{|l|}{ During RT } \\
\hline 2 weeks & $2.39 \pm 0.44$ & $1.78 \pm 0.27$ & 0.30 & $2.77 \pm 0.84$ & $4.13 \pm 1.24$ & 0.35 \\
\hline 4 weeks & $2.3 I \pm 0.74$ & $2.50 \pm 0.80$ & 0.87 & $1.76 \pm 0.54$ & $4.21 \pm 1.17$ & 0.048 \\
\hline Post-RT & $1.51 \pm 0.12$ & $4.59 \pm 1.40$ & 0.02 & $1.70 \pm 0.22$ & $4.37 \pm 1.53$ & 0.025 \\
\hline
\end{tabular}

Note: In both SCLC and NSCLC patients, the TGF- $\beta$ I levels before RT were comparable, patients who experienced an effective response (CR+PR) also had a significantly lower mean TGF- $\beta$ I level after RT compared with whom RT was ineffective (SD+PD).

Abbreviations: CR, complete response; NSCLC, non-small-cell lung cancer; PD, progressive disease; PR, partial response; SCLC, small-cell lung cancer; RT, radiation therapy; SD, stable disease.

an ineffective response (27/35) were higher after RT relative to pre-RT. In the SCLC group specifically, 12 and 9 patients, respectively, experienced effective and ineffective responses to RT (Table 3). Of those who demonstrated an effective response, the majority (11/12) had TGF- $\beta 1$ levels after RT that were lower than the pre-RT levels. The TGF- $\beta 1$ levels of most of the SCLC patients who showed an ineffective response (6/9) were higher after RT relative to pre-RT. In the NSCLC group, 35 and 26 patients experienced effective and ineffective responses to RT, respectively (Table 3). Of those who demonstrated an effective response, the majority $(25 / 35)$ had TGF- $\beta 1$ levels after RT that were lower than pre-RT levels. The TGF- $\beta 1$ levels of most of the SCLC patients who showed an ineffective response $(21 / 26)$ were higher after RT relative to pre-RT.

\section{TGF- $\beta$ I levels and lymphocytes}

Overall, the TGF- $\beta 1$ levels decreased only slightly from pre-RT to post-RT, while the percentages of $\mathrm{CD}^{+} \mathrm{T}$ cells

Table 3 Patients (n) with TGF- $\beta$ I levels at various timepoints after RT (with reference to pre-RT levels) by treatment response

\begin{tabular}{|c|c|c|c|c|}
\hline \multirow{2}{*}{$\begin{array}{l}\text { Fold } \\
\text { change }^{a}\end{array}$} & \multicolumn{2}{|l|}{ SCLC } & \multicolumn{2}{|l|}{ NSCLC } \\
\hline & Effective & Ineffective & Effective & Ineffective \\
\hline \multicolumn{5}{|l|}{2 weeks } \\
\hline$<1$ & 9 & 4 & 25 & 9 \\
\hline$>1$ & 3 & 5 & 10 & 17 \\
\hline \multicolumn{5}{|l|}{4 weeks } \\
\hline$<1$ & 10 & 5 & 27 & 9 \\
\hline$>1$ & 2 & 4 & 8 & 17 \\
\hline \multicolumn{5}{|l|}{ Post-RT } \\
\hline$<1$ & 11 & 3 & 25 & 5 \\
\hline$>1$ & I & 6 & 10 & 21 \\
\hline
\end{tabular}

Notes: aRelative to pre-treatment TGF- $\beta$ I levels. The majority (36/47) of patients who had an effective response, TGF- $\beta$ I levels experienced a drop after RT compared with pre-RT levels. The TGF- $\beta$ I levels of most of the patients who showed an ineffective response (27/35) were higher after RT relative to pre-RT.

Abbreviations: NSCLC, non-small-cell lung cancer; RT, radiation therapy; SCLC, small-cell lung cancer. and B cells were significantly lower at post-RT (both, $P<0.01$; Table 4 ). In addition, compared with pre-RT levels, at post-RT the $\mathrm{CD} 4^{+} \mathrm{T}$ cells and the $\mathrm{CD} 4^{+} / \mathrm{CD} 8^{+}$ratio were only slightly higher; $\mathrm{CD} 8^{+} \mathrm{T}$ cells were higher $(P<0.05$; Table 4); and NK cells remained stable.

At the second and fourth weeks during RT, and at the end of RT, TGF- $\beta 1$ levels were significantly associated with the percentages of $\mathrm{CD} 4^{+} \mathrm{T}$ cells; $\mathrm{CD} 8^{+} \mathrm{T}$ cells; and the $\mathrm{CD} 4^{+} /$ $\mathrm{CD}^{+}$ratio $(P<0.05$, all; Table 5). There were no significant associations between TGF- $\beta 1$ levels and percentages of $\mathrm{CD}^{+}$ $\mathrm{T}$ cells, B cells, or NK cells (Table 5 ).

\section{Discussion}

TGF- $\beta$ is a member of a multifunctional cytokine family, and TGF- $\beta 1$ is considered to participate in carcinogenesis ${ }^{10,11}$ by promoting cell proliferation, differentiation, and extracellular matrix production. ${ }^{12,13}$ Studies have shown that TGF- $\beta 1$ levels may be a marker of patient prognosis; patients with tumors who had higher TGF- $\beta 1$ levels after treatment compared with TGF- $\beta 1$ levels before treatment seemed to have a significantly poorer overall prognosis. ${ }^{2,414}$ This may be due to the immune suppression effect of TGF- $\beta 1$. Zhao et $\mathrm{a}^{9}$ observed that in locally advanced NSCLC, a decrease of TGF- $\beta 1$ levels during RT correlated with a favorable prognosis. Huang et al ${ }^{15}$ reported that high TGF- $\beta 1$ protein levels were associated with a poor prognosis. What is more, studies have reported that chemotherapy may affect TGF- $\beta 1$ levels. Our present small-sample study suggests that patients with decreased TGF- $\beta 1$ levels at the end of RT have a higher response rate, which is in accord with the reported literature. ${ }^{16}$ Patients who received more than 4 cycles of chemotherapy had lower TGF- $\beta 1$ levels compared with those who received fewer than 4 cycles.

The changes of lymphocytes could also be a prognosis biomarker. Results from Yang ${ }^{17}$ showed that the $\mathrm{CD} 4^{+} / \mathrm{CD} 8^{+}$ ratio counts were consistently higher in prostate cancer 
Table 4 TGF- $\beta$ I levels and lymphocyte percentages of 82 patients at 4 timepoints

\begin{tabular}{|c|c|c|c|c|}
\hline & \multirow[t]{2}{*}{ Pre-RT } & \multicolumn{2}{|l|}{ During RT } & \multirow[t]{2}{*}{ Post-RT } \\
\hline & & 2 weeks & 4 weeks & \\
\hline TGF- $\beta I, n g / m L$ & $2.8 I \pm 0.38$ & $2.85 \pm 0.40$ & $2.51 \pm 0.39$ & $2.74 \pm 0.46$ \\
\hline \multicolumn{5}{|l|}{ Lymphocytes, \% } \\
\hline $\mathrm{CD}^{+} \mathrm{T}$ cells & $69.11 \pm 1.71$ & $68.60 \pm 1.81$ & $65.63 \pm 1.64^{a}$ & $62.55 \pm 1.82^{\mathrm{a}}$ \\
\hline $\mathrm{CD4}^{+} \mathrm{T}$ cells & $38.88 \pm 1.45$ & $39.44 \pm 1.67$ & $40.78 \pm 1.81$ & $40.70 \pm 2.18$ \\
\hline $\mathrm{CD}^{+} \mathrm{T}$ cells & $26.45 \pm 1.52$ & $28.00 \pm 1.69$ & $26.73 \pm 1.39$ & $30.23 \pm 2.56^{b}$ \\
\hline $\mathrm{CD}^{+} / \mathrm{CD}^{+}$ & $1.67 \pm 0.11$ & $1.65 \pm 0.13$ & $1.75 \pm 0.12$ & $1.89 \pm 0.19$ \\
\hline B cells & $9.33 \pm 0.64$ & $6.27 \pm 0.4 I^{\mathrm{a}}$ & $7.35 \pm 0.68^{b}$ & $4.21 \pm 0.35^{\mathrm{a}}$ \\
\hline NK cells & $20.73 \pm 1.54$ & $21.41 \pm 1.59$ & $21.04 \pm 1.71$ & $20.4 I \pm I .58$ \\
\hline
\end{tabular}

Notes: a Compared with pre-RT, $P<0.01$; ${ }^{b}$ compared with pre-RT, $P<0.05$. The TGF- $\beta$ I levels decreased only slightly from pre-RT to post-RT, and the percentages of $C D 3^{+}$ $T$ cells and $B$ cells were significantly lower at post-RT. In addition, compared with pre-RT levels, at post-RT the CD4 ${ }^{+} T$ cells and the CD4 ${ }^{+} / C D 8^{+}$ratio were only slightly higher; $C D 8^{+} \mathrm{T}$ cells were higher; and NK cells remained stable.

Abbreviations: NK, natural killer; RT, radiation therapy.

patients with a better response to $\mathrm{RT}$ while $\mathrm{CD} 3^{+}$and $\mathrm{CD} 8^{+}$ cell counts were lower. These results are in accord with our research and indicated that variations in peripheral lymphocyte subpopulations are predictive of outcome after RT. Another research from Spain ${ }^{18}$ indicated that in prostate cancer patients undergoing RT, in vitro radiation-induced apoptosis of $\mathrm{CD}^{+} \mathrm{T}$ lymphocytes assessed before RT was associated with the probability of developing chronic genitourinary toxicity, and radiation-induced apoptosis of $\mathrm{CD}^{+} \mathrm{T}$ lymphocytes was associated with overall survival. In our study, instead of analyzing the probability of $\mathrm{T}$ lymphocytes as a prognostic biomarker, we focused on the relationship between TGF- $\beta 1$ levels and T lymphocytes and hypothesized that the underlying mechanism of TGF- $\beta 1$ could reflect treatment outcome that may be related to the immunosuppression effect of T lymphocytes. Recent studies have indicated that the specific immunologic microenvironment of tumors may be crucial to carcinogenesis and anti-tumorigenesis, ${ }^{19}$ and $\mathrm{T}$ cell-mediated cellular immunity may be an important mechanism for killing tumor cells. ${ }^{20-22}$ Results from Sakaguchi et $\mathrm{a}^{23}$ showed that TGF- $\beta 1$ and interleukin 2 (IL-2) induced tumor tissues to produce more
Treg (regulatory T) cells, which can inhibit the cytotoxic effect of cells, thereby impairing the immune system. ${ }^{23-25}$ Strauss et a ${ }^{26}$ reported that Treg cells with a distinct phenotype in tumor-infiltrating lymphocytes could produce TGF- $\beta$, which contributed to local immune suppression. There can be no doubt that radiotherapy can induce the suppression of immunity, ${ }^{27}$ with significant decline in T lymphocyte levels. ${ }^{28}$ In the present study, we found that after RT the percentage of $\mathrm{CD}^{+} \mathrm{T}$ cells and $\mathrm{B}$ cells had significantly decreased, but the percentage of $\mathrm{CD} 8^{+} \mathrm{T}$ cells significantly increased from pre-RT values. This suggests that the immune system, especially cellular immunity, was inhibited after RT. As for the $\mathrm{CD}^{+} \mathrm{T}$ cells, in our results, after radiotherapy it had a slight rise but did not achieve a statistical significance; therefore, we cannot determine the influence of the change of $\mathrm{CD} 4^{+} \mathrm{T}$ cells on the changes of whole T lymphocyte subsets. Large-sample clinical researches are urgently needed.

Over the course of RT treatment, TGF- $\beta 1$ levels significantly and negatively correlated with the percentages of the $\mathrm{CD} 4^{+} \mathrm{T}$ cells and the $\mathrm{CD} 4^{+} / \mathrm{CD} 8^{+}$ratio, but significantly and positively correlated with the percentages of $\mathrm{CD} 8^{+}$ $\mathrm{T}$ cells. Previously, it was demonstrated that a decrease in

Table 5 Associations between TGF- $\beta$ I levels and lymphocyte percentages

\begin{tabular}{|c|c|c|c|c|c|c|}
\hline & \multicolumn{6}{|c|}{ During RT } \\
\hline & \multicolumn{2}{|c|}{2 weeks } & \multicolumn{2}{|c|}{4 weeks } & \multicolumn{2}{|c|}{ Post-RT } \\
\hline & $r$ & $P$-value & $r$ & $P$-value & $r$ & $P$-value \\
\hline $\mathrm{CD}^{+} \mathrm{T}$ cells & -0.117 & 0.478 & -0.006 & 0.973 & 0.250 & 0.125 \\
\hline $\mathrm{CD} 4^{+} \mathrm{T}$ cells & $-0.58 I$ & 0.023 & -0.516 & 0.037 & -0.648 & $<0.001$ \\
\hline $\mathrm{CD}^{+} \mathrm{T}$ cells & 0.558 & 0.041 & 0.545 & 0.011 & 0.626 & $<0.001$ \\
\hline $\mathrm{CD}^{+} / \mathrm{CD}^{+}$ & -0.615 & 0.024 & -0.648 & 0.003 & -0.598 & $<0.001$ \\
\hline B cells & 0.042 & 0.8 & 0.056 & 0.736 & 0.132 & 0.424 \\
\hline NK cells & -0.301 & 0.063 & -0.292 & 0.073 & -0.298 & 0.066 \\
\hline
\end{tabular}

Notes: At the second and fourth weeks during RT, and at the end of RT, TGF- $\beta$ I levels were significantly associated with the percentages of CD4+ ${ }^{+}$cells; CD8 ${ }^{+}$T cells; and the $\mathrm{CD}^{+} / \mathrm{CD}^{+}$ratio. There were no significant associations between TGF- $\beta$ I levels and percentages of $\mathrm{CD} 3^{+} \mathrm{T}$ cells, $\mathrm{B}$ cells, or NK cells.

Abbreviations: NK, natural killer; $r$, correlation coefficient; RT, radiation therapy. 
the $\mathrm{CD}^{+} / \mathrm{CD}^{+}$ratio was an independent negative prognostic factor for survival in NSCLC patients. ${ }^{29}$ We previously showed that TGF- $\beta 1$ levels negatively correlated with the $\mathrm{CD}^{+} / \mathrm{CD}^{+}$ratio, and an increase in TGF- $\beta 1$ accompanied by a decline in the $\mathrm{CD}^{+} / \mathrm{CD}^{+}$ratio indicates a poor prognosis. This is consistent with previous reports.

\section{Conclusion}

Our research indicated that lung cancer patients with TGF- $\beta 1$ levels in plasma after RT that are below pre-RT levels may experience better short-term efficacy. The underlying mechanism may be related to the influence of TGF- $\beta 1$ on antitumor immunity.

All these results support the hypothesis that the underlying mechanism of TGF- $\beta 1$ may be related to an influence on antitumor immunity, especially cellular immunity. Studies have reported that Treg cells express membrane-bound TGF- $\beta 1$, which directly inhibited the functions of NK effector cells and downregulated NK cell receptors on the NK cell surface. ${ }^{30,31}$ Our present research suggested a weak correlation between TGF- $\beta 1$ and NK cells, but unfortunately, the correlation was not statistically significant. Besides, in our study, one patient with large-cell neuroendocrine carcinoma (LCNEC) was included, considering the current treatment for LCNEC to be the same as NSCLC; 32 therefore, the patient was just classified under the NSCLC group. We failed refining the pathological types into four types (SCLC, adenocarcinoma, squamous cell carcinoma, LCNEC), and hence further exploration is required.

\section{Disclosure}

The authors report no conflicts of interest in this work.

\section{References}

1. Hasegawa Y, Takanashi S, Kanehira Y, Tsushima T, Imai T, Okumura K. Transforming growth factor-beta1 level correlates with angiogenesis, tumor progression, and prognosis in patients with nonsmall cell lung carcinoma. Cancer. 2001;91(5):964-971.

2. Saji H, Nakamura H, Awut I, et al. Significance of expression of TGFbeta in pulmonary metastasis in non-small cell lung cancer tissues. Ann Thorac Cardiovasc Surg. 2003;9(5):295-300.

3. Su YJ, Ren K, Li H, Ren XB, Wang CL. Clinical significance of CD4+ $\mathrm{CD} 25+$ regulatory $\mathrm{T}$-cells detection in tumor-draining lymph nodes of nonsmall cell lung cancer patients. Zhonghua Zhong Liu Za Zhi. 2007;29(12):922-926.

4. Takanami I, Tanaka F, Hashizume T, Kodaira S. Roles of the transforming growth factor beta 1 and its type I and II receptors in the development of a pulmonary adenocarcinoma: results of an immunohistochemical study. J Surg Oncol. 1997;64(4):262-267.

5. Vujaskovic Z, Groen HJ. TGF-beta, radiation-induced pulmonary injury and lung cancer. Int J Radiat Biol. 2000;76(4):511-516.
6. Kong F, Jirtle RL, Huang DH, Clough RW, Anscher MS. Plasma transforming growth factor-beta1 level before radiotherapy correlates with long term outcome of patients with lung carcinoma. Cancer. 1999; 86(9):1712-1719.

7. Akdis M, Aab A, Altunbulakli C, et al. Interleukins (from IL-1 to IL-38), interferons, transforming growth factor $\beta$, and TNF- $\alpha$ : Receptors, functions, and roles in diseases. J Allergy Clin Immunol. 2016;138(4): 984-1010.

8. Young KH, Newell P, Cottam B, et al. TGF $\beta$ inhibition prior to hypofractionated radiation enhances efficacy in preclinical models. Cancer Immunol Res. 2014;2(10):1011-1022.

9. Zhao L, Ji W, Zhang L, et al. Changes of circulating transforming growth factor-betal level during radiation therapy are correlated with the prognosis of locally advanced non-small cell lung cancer. $J$ Thorac Oncol. 2010;5(4):521-525.

10. Lin RL, Zhao LJ. Mechanistic basis and clinical relevance of the role of transforming growth factor- $\beta$ in cancer. Cancer Biol Med. 2015;12(4):385-393.

11. Jakubowska K, Naumnik W, Niklińska W, Chyczewska E. Clinical Significance of HMGB-1 and TGF- $\beta$ Level in Serum and BALF of Advanced Non-Small Cell Lung Cancer. Adv Exp Med Biol. 2015; 852:49-58.

12. Mohammed J, Beura LK, Bobr A, et al. Stromal cells control the epithelial residence of DCs and memory $\mathrm{T}$ cells by regulated activation of TGF-ß. Nat Immunol. 2016;17(4):414-421.

13. Luwor RB, Kaye AH, Zhu HJ. Transforming growth factor-beta (TGFbeta) and brain tumours. J Clin Neurosci. 2008;15(8):845-855.

14. Liu $Y$, Yu H, Zhang C, et al. Protective effects of berberine on radiationinduced lung injury via intercellular adhesion molecular-1 and transforming growth factor-beta-1 in patients with lung cancer. Eur J Cancer. 2008;44(16):2425-2432.

15. Huang AL, Liu SG, Qi WJ, et al. TGF- $\beta 1$ protein expression in nonsmall cell lung cancers is correlated with prognosis. Asian Pac J Cancer Prev. 2014;15(19):8143-8147.

16. Kumar S, Guleria R, Mohan A, Singh V, Bharti AC, das BC. Efficacy of plasma TGF- $\beta 1$ level in predicting therapeutic efficacy and prognosis in patients with advanced non-small cell lung cancer. Cancer Invest. 2011;29(3):202-207.

17. Yang ZR, Zhao N, Meng J, et al. Peripheral lymphocyte subset variation predicts prostate cancer carbon ion radiotherapy outcomes. Oncotarget. 2016;7(18):26422-26435.

18. Foro P, Algara M, Lozano J, et al. Relationship between radiationinduced apoptosis of $\mathrm{T}$ lymphocytes and chronic toxicity in patients with prostate cancer treated by radiation therapy: a prospective study. Int J Radiat Oncol Biol Phys. 2014;88(5):1057-1063.

19. Ke X, Zhang S, Xu J, et al. Non-small-cell lung cancer-induced immunosuppression by increased human regulatory T cells via Foxp3 promoter demethylation. Cancer Immunol Immunother. 2016;65(5):587-599.

20. Banat GA, Tretyn A, Pullamsetti SS, et al. Immune and Inflammatory Cell Composition of Human Lung Cancer Stroma. PLoS One. 2015; 10(9):e0139073.

21. Mori A, Deola S, Xumerle L, Mijatovic V, Malerba G, Monsurrò V. Next generation sequencing: new tools in immunology and hematology. Blood Res. 2013;48(4):242-249.

22. Hanahan D, Weinberg RA. Hallmarks of cancer: the next generation. Cell. 2011;144(5):646-674.

23. Sakaguchi S, Miyara M, Costantino CM, Hafler DA. FOXP3+ regulatory T cells in the human immune system. Nat Rev Immunol. 2010;10(7): 490-500.

24. Schmidt A, Eriksson M, Shang MM, Weyd H, Tegnér J. Comparative Analysis of Protocols to Induce Human CD4+Foxp3+ Regulatory T Cells by Combinations of IL-2, TGF-beta, Retinoic Acid, Rapamycin and Butyrate. PLoS One. 2016;11(2):e0148474. 
25. Wilson S, Levy D. A mathematical model of the enhancement of tumor vaccine efficacy by immunotherapy. Bull Math Biol. 2012;74(7): 1485-1500.

26. Strauss L, Bergmann C, Szczepanski M, Gooding W, Johnson JT, Whiteside TL. A unique subset of CD4+CD25highFoxp3+ T cells secreting interleukin-10 and transforming growth factor-beta1 mediates suppression in the tumor microenvironment. Clin Cancer Res. 2007; 13(15 Pt 1):4345-4354.

27. Ng J, Dai T. Radiation therapy and the abscopal effect: a concept comes of age. Ann Transl Med. 2016;4(6):118.

28. Zhao D, Yin L, Xu K, Zhao K. [Effect on T cell subsets and secretion of IFN- $\gamma$ and IL-17 after exposure to ${ }^{60} \mathrm{Co}$ lethally total body irradiation in mice]. Zhonghua Xue Ye Xue Za Zhi. 2014;35(11):1005-1008. Chinese

29. Hald SM, Bremnes RM, Al-Shibli K, et al. CD4/CD8 co-expression shows independent prognostic impact in resected non-small cell lung cancer patients treated with adjuvant radiotherapy. Lung Cancer. 2013;80(2):209-215.
30. Ghiringhelli F, Ménard C, Terme M, et al. CD4+CD25+ regulatory $\mathrm{T}$ cells inhibit natural killer cell functions in a transforming growth factor-beta-dependent manner. J Exp Med. 2005;202(8): 1075-1085.

31. Castriconi R, Cantoni C, della Chiesa M, et al. Transforming growth factor beta 1 inhibits expression of NKp30 and NKG2D receptors: consequences for the NK-mediated killing of dendritic cells. Proc Natl Acad Sci U S A. 2003;100(7):4120-4125.

32. Filosso PL, Guerrera F, Evangelista A, et al. Adjuvant chemotherapy for large-cell neuroendocrine lung carcinoma: results from the European Society for Thoracic Surgeons Lung Neuroendocrine Tumours Retrospective Database. Eur J Cardiothorac Surg. 2017;52(2):339-345.

\section{Publish your work in this journal}

OncoTargets and Therapy is an international, peer-reviewed, open access journal focusing on the pathological basis of all cancers, potential targets for therapy and treatment protocols employed to improve the management of cancer patients. The journal also focuses on the impact of management programs and new therapeutic agents and protocols on

\section{Dovepress}

patient perspectives such as quality of life, adherence and satisfaction. The manuscript management system is completely online and includes a very quick and fair peer-review system, which is all easy to use. Visit http://www.dovepress.com/testimonials.php to read real quotes from published authors.

Submit your manuscript here: http://www.dovepress.com/oncotargets-and-therapy-journal 